\title{
Hail and Farewell
}

\author{
Curtis W. Hart ${ }^{1}$
}

Accepted: 23 October 2020 / Published online: 5 November 2020

(c) Springer Science+Business Media, LLC, part of Springer Nature 2020

This is my final word as Editor in Chief after what has been a fulfilling journey of 10 years in this position that concludes officially on December 31 of this year. When I commenced in my role as Editor in Chief of the Journal of Religion and Health 10 years ago, I had not a clue for how long I would be here. I had a personal history of long tenures in previous professional positions I had held, but aside from that record, I did not have any clear idea of what it would take for me to complete my initial objectives. They were, first, to provide a place where young scholars and clinicians might publish their work and thus assist in developing a next generation of contributors to the field, second, develop a series of Special Sections consisting of articles in discrete areas of interest published as part of online and print issues and guest-edited by acknowledged leaders in their respective fields, and third, provide ample opportunity for scholars in all parts of the world to share their efforts with a wide readership. All this took 10 years to accomplish even as the Journal has expanded from four to six issues a year. Our articles are regularly recognized as among the finest in the field of religion, spirituality, and health in the monthly Research Review published by the Institute for the Bio-Cultural Study of Religion. This last accomplishment was unexpected at the start of my tenure and is due primarily to the quality of authorship of submissions, a careful selection for publication, and an effective peer review process.

I am deeply indebted to those at Springer with whom I have worked during this last decade, particularly our Senior Editor Carol Bischoff and our able and generous assistants at Springer Subaysala Ravichandran and Hemalatha Vedachalam. These latter two persons assisted me in negotiating the vagaries of Editorial Manager and Production even as they faithfully answered both my and our authors' questions.

In any publishing venture, there is always the matter of tradition. You see it in publishing houses that engage editors who are the heart and soul of bringing books and articles to life in print. It is my good fortune to have known all my predecessors in the editor's chair of the Journal. Homage is due them all. I did not ever meet Harry Meserve in person but corresponded with him about articles I wrote and ones I had submitted on behalf of my professional colleagues. Ann Ulanov was both my

Curtis W. Hart

cuh9001@med.cornell.edu

1 New York, USA 
teacher and mentor who in her persuasive and good-natured way would periodically chide me with "Well, Curtis, what are you writing?" Her manner reminded me of my days in boarding school when my then teachers were forever reminding me not to waste time and always use my talents to good effect. Her spouse and editorial partner, Barry Ulanov, was an extraordinary editor who could take a good manuscript and with speed and scrupulous attention to detail make it better. He was the master of "le mot juste." Whenever I was perplexed about an editorial decision, I would find myself thinking, "What would Barry do?" David Leeming lifted the Journal a peg higher during his tenure. Few may know that he is the author of the authoritative biography of James Baldwin (1994) based on his longstanding relationship with Baldwin as his personal secretary and literary confidante. And, finally, Donald Ferrell who handed the reigns over to me was progressive and dedicated as the Journal's editor who prepared the way as it began its accelerated growth. To all of them, I owe more than these few words can express. I am honored to stand with them after my tenure concludes as among those noted in the Journal as Former Editors.

I can only wish that my successor Lindsay Carey will have as rewarding a tenure as mine has been. He is well prepared as you will come to know. After having been both a reviewer and author, he has moved on to become an Associate Editor. He is possessed of a clear sense of what it means to edit and what it will take to raise the Journal of Religion and Health to new levels of excellence as it enters a new era in its history.

Publisher's Note Springer Nature remains neutral with regard to jurisdictional claims in published maps and institutional affiliations. 